\title{
Zastosowanie laseroterapii w chorobach siatkówki. Część II
}

\author{
The use of laser therapy in retinal diseases. Part Il
}

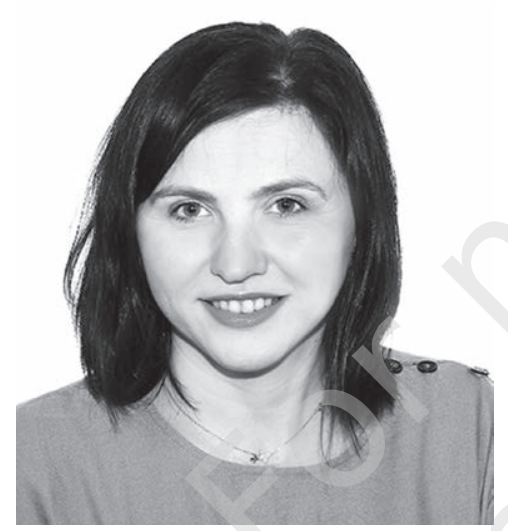

N A J W A ŻN IE J S ZE

Mimo prób wprowadzania do terapii schorzeń siatkówki innych metod leczniczych laseroterapia nadal pozostaje jedną z głównych opcji terapeutycznych.

H I G H LI GHTS Despite introduction of other potentially innovative, beneficial and successful therapeutic methods, lasers are still considered the gold standard in the treatment of several retinal diseases.

\section{Katarzyna Warzecha' ${ }^{1}$, Agnieszka Tronina², Erita Filipek ${ }^{2,3}$}

${ }^{1}$ Oddział Okulistyki Dorosłych, Uniwersyteckie Centrum Kliniczne im. prof. K. Gibińskiego,

Śląski Uniwersytet Medyczny w Katowicach

Kierownik Katedry i Kliniki: prof. dr hab. n. med. Ewa Mrukwa-Kominek

${ }^{2}$ Oddział Okulistyki Dziecięcej, Uniwersyteckie Centrum Kliniczne im. prof. K. Gibińskiego,

Śląski Uniwersytet Medyczny w Katowicach

Kierownik Oddziału: dr hab. n. med. Erita Filipek

${ }^{3}$ Klinika Okulistyki Dziecięcej, Katedra Okulistyki, Wydział Lekarski, Śląski Uniwersytet Medyczny w Katowicach Kierownik Kliniki: dr hab. n. med. Erita Filipek

\section{STRESZCZENIE}

Choroby siatkówki stanowią dużą grupę schorzeń narządu wzroku. W leczeniu wielu z nich od lat z powodzeniem jest stosowana laseroterapia. Mimo prób wprowadzania innych metod leczniczych nadal pozostaje ona jedną z głównych opcji terapeutycznych. W pracy przedstawiono przegląd piśmiennictwa dotyczący zastosowania laseroterapii w chorobach siatkówki, z uwzględnieniem nowych rodzajów i sposobów tej formy leczenia. Pracę podzielono na trzy części. W pierwszej, która ukazała się w poprzednim numerze, przedstawiono metodykę i rodzaje zabiegów laserowych. Część druga, publikowana w niniejszym numerze, zawiera przegląd piśmiennictwa dotyczący laseroterapii w retinopatii cukrzycowej, cukrzycowym obrzęku plamki oraz chorobach naczyniowych siatkówki. Trzecia część, która ukaże się w kolejnym numerze, zaprezentuje przegląd piśmiennictwa dotyczący laseroterapii w przedarciach oraz chorobach zwyrodnieniowych siatkówki, retinopatii wcześniaków, zwyrodnieniu plamki związanym z wiekiem oraz innych chorobach siatkówki.

Słowa kluczowe: laseroterapia, choroby siatkówki, micropulse therapy

\section{ABSTRACT}

Retinal diseases account for the vast majority of ophthalmologic disorders. Over the past years, laser-based approach has been successfully used. Despite introduction of other potentially innovative, beneficial and successful therapeutic methods, lasers are still considered the gold standard. In this review, we discuss the spectrum of currently prevailing laser methods and we give a new insight into novel perspectives and techniques regarding laser management of retinal disorders. This paper is divided into three sections. The current one consists of a literature review that investigates the existing knowledge in laser management of diabetic retinopathy, diabetic macular edema and vascular retinal disorders. Finally, it outlines the principles guiding laser treatment of retinal tears, retinal degeneration, retinopathy of prematurity, age-related macular degeneration and other retinal diseases.

Key words: laser therapy, retinal diseases, micropulse therapy 


\section{LASEROTERAPIA W RETINOPATII CUKRZYCOWEJ}

Z danych opublikowanych przez Światową Organizację Zdrowia (WHO) wynika, że według szacunków w 2014 r. na świecie żyło 422 mln dorosłych z cukrzycą (dla porównania - w 1980 r. było ich 108 mln). W Polsce cukrzyca dotyka ok. $3 \mathrm{mln}$ osób. Retinopatia cukrzycowa (DR, diabetic retinopathy) stanowi główną przyczynę ślepoty na świecie. Na jej rozwój, oprócz stopnia wyrównania cukrzycy, współistniejącego nadciśnienia tętniczego, zaburzeń gospodarki lipidowej, schorzeń nerek, stanu naczyń krwionośnych, wieku pacjenta czy poziomu aktywności fizycznej wpływ ma również czas trwania cukrzycy. Występowanie DR wzrasta wraz z czasem trwania choroby i wynosi dla cukrzycy typu I: $25 \%$ po 5 latach, $60 \%$ po 10 latach i $80 \%$ po 15 latach trwania choroby [1-3]. W cukrzycy typu II, wśród osób leczonych do 5 lat lekami doustnymi powikłania w postaci retinopatii cukrzycowej rozwinie 24\%, a przy leczeniu do 19 lat ryzyko wzrasta do 53\%. Przy konieczności insulinoterapii będzie to odpowiednio $40 \%$ i $84 \%[1,4,5]$.

Retinopatia cukrzycowa według Early Treatment Diabetic Retinopathy Study (ETDRS) dzieli się na nieproliferacyjną retinopatię cukrzycową (NPDR, non-proliferative diabetic retinopathy) oraz proliferacyjną retinopatię cukrzycową (PDR, proliferative diabetic retinopathy). Oba typy dzielą się na stopnie, zależnie od zaawansowania zmian cukrzycowych obserwowanych na dnie oka [6]. W każdym stadium DR może występować cukrzycowy obrzęk plamki (DME, diabetic macular edema) [1], który zostanie omówiony jako osobne zagadnienie.

Klasyczna fotokoagulacja panretinalna (PRP, panretinal photocoagulation) jest standardem w leczeniu ciężkiej postaci NPDR lub PDR. Jej skuteczność potwierdzają wyniki badań Diabetic Retinopathy Study (DRS) i ETDRS [7-9]. W związku z działaniami niepożądanymi w postaci ubytków w polu widzenia, jakie powoduje PRP, poszukiwano innych metod terapeutycznych, które oszczędzałyby siatkówkę obwodową. Terapia anty-VEGF została wypróbowana jako alternatywa dla PRP z funkcjonalnym sukcesem; wymaga jednak regularnych zastrzyków do ciała szklistego i licznych wizyt kontrolnych, co może stanowić problem [7, 10, 11].

Testowano również laser mikropulsowy jako alternatywę do PRP [7]. Jak dotąd wyniki są obiecujące: fotokoagulacja panretinalna przy użyciu lasera mikropulsowego (SMPLT PRP) wydawała się nie gorsza od klasycznej PRP, z zachowaniem większej wrażliwości siatkówki. W tym momencie jednak tego rodzaju leczenie należy uznać za eksperymentalne [7]. Brak jest wytycznych Polskiego Towarzystwa Okulistycznego (PTO) na temat postępowania w DR.

Badania kliniczne oraz wytyczne Diabetes Association i American Academy of Ophthalmology wykazują, że prawidłowo zastosowane schematy terapeutyczne mogą skutecznie chronić przed znaczną utratą widzenia nawet
90\% pacjentów. Zwraca się szczególną uwagę na rolę badań przesiewowych oraz edukacji pacjentów z cukrzycą [1]. Jeżeli u pacjenta występuje lub zagraża mu także cukrzycowy obrzęk plamki, fotokoagulacje zmian powinny być wykonane przed PRP lub w ramach jednego zabiegu [6].

\section{LASEROTERAPIA W CUKRZYCOWYM OBRZĘKU PLAMKI}

Cukrzycowy obrzęk plamki (DME, diabetic macular edema) może występować w każdym stadium retinopatii cukrzycowej. Według ETDRS pojęcie klinicznie znamiennego obrzęku plamki jest dziś rzadko używane. ETDRS proponuje podział obrzęku plamki na łagodny, umiarkowany i zaawansowany DME w zależności od lokalizacji obrzęku i wysięków twardych w stosunku do dołeczka [1].

Badaniami dodatkowymi pozwalającymi w sposób precyzyjny określić i udokumentować obrzęk plamki są optyczna koherentna tomografia (OCT, optical coherence tomography) oraz angiografia fluoresceinowa (AF).

Obecnie bardziej praktyczny wydaje się podział obrzęku plamki na podstawie badania OCT, który wyróżnia DME lokalny (obejmujący centrum plamki lub zlokalizowany poza nim), rozlany (obejmujący cały obszar plamkowy) oraz trakcyjny (w którym siatkówka unoszona jest mechanicznie przez trakcję szklistkowo-siatkówkową) [1].

Zarówno w leczeniu lokalnego obrzęku plamki, jak i retinopatii cukrzycowej zgodnie ze schematami ETDRS od wielu lat złoty standard stanowi laseroterapia siatkówki [1].

W przypadku obrzęku plamki poza centrum (obrzęk nieobejmujący dołeczka) leczenie za pomocą laseroterapii uznaje się za skuteczne. Jednakże w przypadku obrzęku plamki obejmującego dołeczek lub obrzęku rozlanego większą skuteczność wykazują inhibitory VEGF, zgodnie z badaniami. Terapię łączoną - laseroterapię i podania do ciała szklistego inhibitorów VEGF - uznaje się za znacznie skuteczniejszą niż samą laseroterapię [1, 12-14].

Rekomendacje European Society of Retina Specialists (EURETINA) są następujące: pomimo że laseroterapia $\mathrm{w}$ wielu badaniach okazała się skuteczną metodą leczenia DME w porównaniu z placebo, w erze terapii anty-VEGF nie jest już złotym standardem leczenia DME. Względne wskazanie do zastosowania lasera stanowi naczyniowa odmiana DME, która charakteryzuje się obecnością koncentrycznie zgrupowanych mikrotętniaków i przecieków kapilarnych. Wskazaniem jest również DME z centralną grubością siatkówki poniżej $300 \mu \mathrm{m}$ lub utrzymująca się adhezja ciała szklistego w okolicy plamki - tu wyniki terapii przy użyciu laseroterapii i preparatów anty-VEGF są porównywalne $[15,16]$.

Laseroterapia mikropulsowa może być pomocna u pacjentów z lepszą ostrością wzroku, a jej wynik jest uzależniony od wczesnego rozpoznania DME. Leczenie wdrożone w początkowych fazach DME pozwala uniknąć uszkodzenia 
fotoreceptorów, błony Brucha oraz naczyniówki [15, 16]. Nadal jednak brakuje dużych prospektywnych badań potwierdzających skuteczność tej metody [17].

Wyniki terapii laserem 2RT (retina regeneration therapy) firmy Ellex w leczeniu obszaru wokół plamki są bardzo zbliżone do wyników standardowego leczenia fotokoagulacją mimo zastosowania 500-krotnie mniejszej energii $[18,19]$. Tu również brakuje badań potwierdzających skuteczność tej metody.

Wytyczne postępowania w terapii DME według PTO uzależniają postępowanie od lokalizacji i charakteru obrzęku plamki:

- gdy jest on ogniskowy i zlokalizowany w odległości większej niż $500 \mu \mathrm{m}$ od centrum dołka zalecana jest fotokoagulacja laserem ogniskowym lub GRID (fotokoagulacja każdego mikrotętniaka w odległości 500-3000 $\mu \mathrm{m}$ od centrum plamki), lub terapia doszklistkowa anty-VEGF (gdy istnieją przeciwwskazania do laseroterapii)

- gdy jest ogniskowy i zlokalizowany w odległości mniejszej niż $500 \mu \mathrm{m}$ od centrum dołka, zalecana jest terapia doszklistkowa anty-VEGF lub laser mikropulsowy (gdy istnieją przeciwwskazania do anty-VEGF)

- gdy obrzęk jest miejscowy z zajęciem dołka lub rozlany (klinicznie znamienny obrzęk plamki), zalecana jest terapia doszklistkowa anty-VEGF, laser mikropulsowy (gdy istnieją przeciwwskazania do anty-VEGF) lub glikokortykosteroidy (w przypadku przeciwwskazań do powyższych metod leczenia; w oczach pseudofakijnych)

- w przypadku obrzęku plamki z trakcją szklistkowo-siatkówkową lub błoną nasiatkówkową preferowana jest witrektomia tylna (PPV, pars plana vitrectomy) [20].

\section{LASEROTERAPIA W LECZENIU POWIKŁAŃ ZAKRZEPU ŻYŁ SIATKÓWKI}

Zakrzep żyły centralnej siatkówki (CRVO, central retinal vein occlusion) lub jej gałęzi (BRVO, branch retinal vein occlusion) zajmuje drugie, po DR i jej następstwach, miejsce wśród chorób siatkówki o podłożu naczyniowym prowadzących do obniżenia ostrości widzenia. Częstość występowania CRVO u osób powyżej 40. r.ż. wynosi $0,1 \%-0,4 \%$. Ze względu na rokowanie co do widzenia i ryzyko powikłań wyróżnia się dwa typy zakrzepów: niedokrwienny i bez niedokrwienia. Szacunkowo w okresie do 3 miesięcy od wystąpienia choroby u 75\% występuje postać bez niedokrwienia, jednak u części chorych dochodzi do progresji w postać niedokrwienną w późniejszym czasie. Niezależnie od postaci i przebiegu zakrzepu żyły środkowej siatkówki może dojść do wystąpienia obrzęku plamki prowadzącego do obniżenia ostrości widzenia [21].

\section{Zakrzep żyły centralnej siatkówki}

Istotne jest rozróżnienie postaci niedokrwiennej od postaci bez niedokrwienia ( $w$ przypadku zakrzepu z niedokrwieniem istnieje dużo większe ryzyko powikłań związanych z neowaskularyzacją) [22, 23].

Wykonanie pilnej PRP jest konieczne w przypadku stwierdzenia neowaskularyzacji tęczówki (NVI, new vessels iridis) lub w kącie przesączania [6], czyli w okresie późnych powikłań, takich jak jaskra neowaskularna.

Li i wsp. dokonali oceny skuteczności terapii laserowej w niedokrwiennym zamknięciu CRVO na podstawie wielu publikacji. Przegląd systematyczny wykazał, że fotokoagulacja laserowa nie wydaje się skuteczna w poprawie ostrości wzroku, za to w zapobieganiu powikłaniom jest skuteczna [23]. Grubość siatkówki w plamce, wystąpienie obrzęku plamki, grubość i gęstość warstwy zwojowej siatkówki u pacjentów leczonych wczesną PRP są istotnie niższe w porównaniu z grupą kontrolną pacjentów nieleczonych lub leczonych za pomocą późnej laseroterapii siatkówki [22, 23]. Mimo tych doniesień nie ma jednoznacznego stanowiska dotyczącego profilaktycznej PRP i potrzebne są dalsze badania oceniające skuteczność tej metody leczenia [22-25].

\section{Zakrzep gałęzi żyły centralnej siatkówki}

Torbielowaty obrzęk plamki żółtej (CME, cystoid macular edema) jest główną przyczyną upośledzenia widzenia z powodu BRVO i występuje w 30\% oczu BRVO [26, 27]. W leczeniu stosuje się laseroterapię siatkówki, iniekcje doszklistkowe anty-VEGF, glikokortykosteroidy, niesteroidowe leki przeciwzapalne.

Laseroterapia siatkówki obwodowej typu scatter może zmniejszyć niedokrwienie siatkówki. Teoretycznie może to zapewnić sposób na przerwanie pętli dodatniego sprzężenia zwrotnego u pacjentów z BRVO i zmniejszenie potrzeby wstrzykiwania antagonisty VEGF. Jednak badanie RELATE wykazało, że laser siatkówki obwodowej nie przyniósł korzyści w poprawie ostrości wzroku, zmniejszeniu obrzęku lub liczbie iniekcji preparatu anty-VEGF (ranibizumabu) $[26,28]$.

Leczenie obrzęku plamki, podobne jak cukrzycowego obrzęku plamki, zostało zrewolucjonizowane przez preparaty anty-VEGF.

Opisywanych jest wiele metod leczenia BRVO. Badacze wielokrotnie stosowali terapię skojarzoną $\mathrm{z}$ dwoma lub więcej środkami w celu uzyskania lepszych wyników przy zmniejszonej dawce, mniejszej częstości zdarzeń niepożądanych i rzadszym stosowaniu. Wielokrotne wstrzyknięcia do ciała szklistego anty-VEGF mogą powodować działania niepożądane, takie jak: ból oka, retinopatia niedokrwienna i zapalenie wnętrza gałki ocznej, a także generują wysokie koszty leków anty-VEGF, takich jak ranibizumab [26, 29, 30]. Doniesiono, że bewacyzumab w połączeniu z laseroterapią typu GRID plamki i fotokoagulacją laserową obwodowych 
stref bezperfuzyjnych siatkówki może znacznie poprawić widzenie, zmniejszyć obrzęk plamki i zapobiec nawrotowi CME lepiej niż sam bewacyzumab [26, 31, 32]. Ponadto $\mathrm{w}$ leczeniu skojarzonym zaobserwowano mniejszą liczbę ponownych wstrzyknięć $[26,33]$. Stwierdzono, że zastosowanie miejscowo bromfenaku, niesteroidowego leku przeciwzapalnego, w oczach z obrzękiem plamki wtórnym do BRVO ma tę zaletę, że zmniejsza liczbę wstrzyknięć, chociaż nie wpływa na ostrość widzenia [26, 34]. Inne badane terapie skojarzone to glikokortykosteroidy z laserem, preparaty anty-VEGF $\mathrm{z}$ glikokortykosteroidami, preparaty anty-VEGF z laserem i sheatotomia, czyli nacięcie pochewki naczyń (AVS) lub PPV z glikokortykosteroidami [26, 35-43]. Chociaż większość z tych badań wykazała doskonałe wyniki, trudno jest dokonać porównania między badaniami, aby ustalić, która kombinacja jest najlepsza [26].

W leczeniu RVO wypróbowano także laser mikropulsowy. Teoretycznie podprogowe leczenie laserem mikropulsowym (SMPLT) powinno zmniejszyć stan zapalny i poprawić eliminację płynów dzięki stymulacji nabłonka barwnikowego siatkówki (RPE, retinal pigment epithelium) - następuje produkcja cytokin i zwiększenie aktywności pompowania. W zakrzepie żył siatkówki (RVO, retinal vein occlusion) procesy zapalne i przepuszczalność naczyń są prawdopodobnie bardziej intensywne w porównaniu z innymi chorobami naczyń siatkówki. To może wyjaśniać, dlaczego wyniki SMPLT obrzęku plamki wtórnego do zakrzepu żył siatkówki nie zawsze są zadowalające. W tych przypadkach SMPLT prawdopodobnie nie jest wystarczająco silny, aby przeważyć korzyści płynące ze stosowania steroidów do ciała szklistego lub leczenia anty-VEGF [7]. Zdecydowanie potrzebne są dalsze badania, aby znaleźć miejsce SMPLT w leczeniu obrzęku plamki w RVO [7].

Wytyczne PTO dotyczą jedynie postępowania w obrzęku plamki wtórnego do RVO i są następujące: leczeniem zatwierdzonym i powszechnie stosowanym w leczeniu obrzęku plamki w przebiegu zakrzepu żyły środkowej siatkówki są iniekcje doszklistkowe anty-VEGF lub deksametazonu w postaci implantu. Należy również podkreślić, iż ze względu na możliwość wystąpienia odległych powikłań zarówno neowaskularyzacji, jak i obrzęku plamki szczególnie ważna jest obserwacja pacjenta i jego kontrole w ciągu 2 lat od wystąpienia zakrzepu [21].

Wytyczne EURETINA dotyczące postępowania w obrzęku plamki wtórnym do RVO jako główne opcje terapeutyczne przedstawiają iniekcje anty-VEGF oraz implanty doszklistkowe ze steroidów w różnym zindywidualizowanym schemacie podawania. Alternatywne terapie, takie jak: witrektomia, peeling ILM i sheatotomia tętniczo-żylna, mogą odgrywać rolę w wybranych przypadkach BRVO. Obecne dowody na terapię porównawczą we wszystkich klasach leków i w ich obrębie są ograniczone. Brakuje również solidnych dowodów na leczenie skojarzone. Istnieje konieczność zindywidualizowanego podejścia do każdego pacjenta w oparciu o cechy podstawowe i odpowiedź na leczenie [44].

\section{LASEROTERAPIA W ZATORACH TĘTNICY ŚRODKOWEJ SIATKÓWKI}

Aktualna klasyfikacja zatoru (CRAO, central retinal artery occlusion) obejmuje:

- zator tętnicy środkowej siatkówki nietętniczy trwały (central retinal artery occlusion non-arteritic permanent)

- zator tętnicy środkowej siatkówki nietętniczy przejściowy (central retinal artery occlusion non-arteritic transient)

- zator tętnicy środkowej siatkówki nietętniczy z zaoszczędzeniem tętnicy rzęskowo-siatkówkowej (central retinal artery occlusion non-arteritic with cilioretinal sparing)

- tętniczy zator tętnicy środkowej siatkówki (arteric central retinal artery occlusion), najczęściej związany z olbrzymiokomórkowym zapaleniem tętnicy skroniowej

- zator gałązki tętnicy środkowej siatkówki (BRAO, branch retinal artery occlusion) [22, 45].

Zatory są najczęściej pochodzenia miażdżycowego, mogą być złożone z cholesterolu, złogów włóknisto-płytkowych, złogów wapniowych, rzadziej z sercowego materiału śluzowatego, materiału z bakteryjnego zapalenia wsierdzia, tłuszczu czy innych substancji [6].

Zgodnie z definicją udaru ośrodkowego układu nerwowego (OUN) według American Stroke Association CRAO mieści się w tej definicji, niosąc za sobą konieczność diagnostyki i leczenia jak w przypadku tych udarów [22].

W ostrym okresie choroby, oprócz metod nieinwazyjnych (pozycja na wznak, masaż gałki ocznej, leki obniżające ciśnienie wewnątrzgałkowe czy hiperosmotyczna mieszanka oddechowa o zwiększonej zawartości dwutlenku węgla) [6], były również podejmowane próby zastosowania embolektomii za pomocą lasera Nd:YAG (TYL/E, transluminal Nd:YAG embolisis/embolectomy) [22, 6, 46]. Konieczne jest stwierdzenie materiału zatorowego widocznego na dnie oka. Wiązka laserowa ogniskowana jest bezpośrednio na materiale zatorowym z zastosowaniem zwiększonej mocy lasera (0,3-1,0 mJ, zależnie od źródła) aż do uzyskania fragmentacji materiału zatorowego (emboliza) lub do uwolnienia go przez niewielki otworek w ścianie naczynia krwionośnego do komory ciała szklistego (embolektomia) [22, 6, 46]. Pojawiły się również doniesienia o terapii łączonej embolektomii za pomocą lasera Nd:YAG z następowym stosowaniem urokinazy przez 5 dni po laseroterapii [22, 47]. Z dostępnych publikacji wynika, że u większości pacjentów uzyskuje się reperfuzję w obrębie siatkówki $(100 \%$ [22, 46] i 44,1\% [22, 47]). Trudno 
jest ocenić skuteczność obu metod z uwagi na niewielką liczbę dostępnych doniesień i małą grupę chorych poddanych leczeniu, dlatego nie zaleca się tej metody jako rutynowej terapii $[22,45]$.

W podostrej i długoterminowej terapii pacjentów po zatorach tętnicy i gałązki tętnicy środkowej siatkówki najistotniejsze jest na zapobieganie powstawaniu i/lub redukcja już istniejących miejsc niedokrwienia siatkówki oraz ryzyka wystąpienia jaskry neowaskularnej [22, 45]. Do oceny dna oka pod względem ewentualnej laseroterapii konieczna jest AF $[6,22]$.

\section{LASEROTERAPIA W OCZNYM ZESPOLE NIEDOKRWIENNYM}

Oczny zespół niedokrwienny (IOS, ocular ischaemic syndrome) jest rzadkim stanem będącym rezultatem przewlekłej hipoperfuzji wtórnej do zwężających tętnice szyjne w więcej niż w 90\% płytek wapniowych. Typowo chorują pacjenci w 7. dekadzie życia, często z cukrzycą, nadciśnieniem, chorobą niedokrwienną serca i schorzeniami naczyniowo-mózgowymi (częściej mężczyźni). Pacjenci z IOS mogą mieć w wywiadzie przejściowe jednooczne zaniewidzenie (AFx, amaurosis fugax) z powodu zatoru tętnicy siatkówki [6].

Objawia się zazwyczaj znacznym spadkiem ostrości wzroku w ciągu kilku tygodni lub miesięcy, czasami z AFx. Może mu towarzyszyć ból oka i jego okolicy (w 40\% przypadków). W badaniu okulistycznym stwierdzamy objawy zarówno w odcinku przednim (m.in. obrzęk rogówki, tyndalizacja w przedniej komorze, słaba reakcja źrenicy na światło, rubeoza tęczówki, która często prowadzi do jaskry wtórnej), jak i w tylnym (m.in. poszerzenie żył, zwężenie tętniczek, czasem obrzęk tarczy nerwu II, retinopatia proliferacyjna z neowaskularyzacją na tarczy nerwu II [NVD, neovascularization on the disc], i czasem neowaskularyzacją poza tarczą nerwu II [NVE, neovascularization elsewhere], czasem obrzęk plamki [6].

Terapia IOS powinna obejmować leczenie przyczynowe i objawowe. Wymaga ona współpracy lekarzy kilku specjalności, m.in.: chirurga naczyniowego, okulisty, kardiologa, neurologa, neurochirurga. Leczenie przyczynowe polega na udrożnieniu zwężonej tętnicy szyjnej [48, 49]. Leczenie objawowe ma na celu zmniejszenie odczynu zapalnego, kontrolę ciśnienia wewnątrzgałkowego i zmniejszenie obszarów braku perfuzji na siatkówce [48].

Panfotokoagulacja siatkówki u niektórych pacjentów z NVI może zapobiec rozwinięciu się jaskry neowaskularnej, w przypadku nieprzejrzystych ośrodków optycznych należy rozważyć krioretinopeksję. Inną opcją terapeutyczną jest doszklistkowe podanie preparatów blokujących czynnik wzrostu śródbłonka (anty-VEGF) [48, 50]. Preparaty
anty-VEGF oraz steroidy mogą być również wykorzystywane w leczeniu obrzęku plamki wtórnego do IOS [6].

\section{LASEROTERAPIA W CENTRALNEJ SUROWICZEJ RETINOPATII}

Centralna surowicza retinopatia (CRS, central serous retinopathy) jest schorzeniem idiopatycznym charakteryzującym się ograniczonym surowiczym odwarstwieniem siatkówki sensorycznej w plamce w wyniku przecieku choriokapilar wtórnie do uszkodzenia RPE. CRS występuje przede wszystkim u mężczyzn rasy kaukaskiej, młodych lub w średnim wieku. U kobiet CRS występuje w wieku starszym. Dodatkowymi czynnikami ryzyka są: stres psychiczny, osobowość typu A, przyjmowanie steroidów, choroba Cushinga i ciąża. Choroba objawia się jednostronnymi metamorfopsjami z makropsją, umiarkowaną dyschromatopsją i obniżonym poczuciem kontrastu [6].

Morfologicznie CRS przedstawia nagromadzenie surowiczego płynu pod siatkówką neurosensoryczną. Obszarom płynu podsiatkówkowego czasami towarzyszą oderwania RPE (oderwanie nabłonka pigmentowego [PED, pigment epithelial detachment]) i zmiany RPE (atrofia lub przerost) charakterystyczne dla przewlekłej postaci CRS. Współcześnie uważa się, że źródło patologii w CRS leży raczej w naczyniówce niż w siatkówce [7, 51-53].

W 80\% przypadków następuje samoistne wchłonięcie się płynu podsiatkówkowego w ciągu 3-6 miesięcy. Nawroty zdarzają się u połowy pacjentów. Przewlekły przebieg choroby, powyżej 12 miesięcy, występuje bardzo rzadko i zwykle dotyczy pacjentów > 50. r.ż. [6].

Fotokoagulacja laserem argonowym miejsca przecieku RPE nie jest obecnie rekomendowana. Dużą nadzieję pokłada się w nowych metodach terapii, jak np. w laserze mikropulsowym zastosowanym na RPE w okolicy przecieku [6].

Gawęcki porównuje wyniki wielu doniesień i zauważa, że większość badań ujawnia wysoką skuteczność SMPLT w poprawie morfologii siatkówki w przewlekłym CRS. Jednak pełną resorbcję płynu podsiatkówkowego (SRF, subretinal fluid) uzyskuje się w 60-80\% przypadków. Ponadto poprawa najlepszej skorygowanej ostrości wzroku (BCVA, best corrected visual acuity) po leczeniu zwykle nie jest lepsza niż jedna linia na wykresie Snellena [7].

Arora i wsp. porównali wyniki wczesnego leczenia CRS z obserwacją [7, 54]. Pacjenci, którzy przeszli SMPLT w ostrej fazie CRS, mieli lepszą końcową BCVA i lepszą wrażliwość na kontrast niż pacjenci, którzy zostali poddani obserwacji [7].

Nie należy również zapominać o możliwości leczenia CRS za pomocą terapii fotodynamicznej (PDT) czy preparatów anty-VEGF [6]. 


\author{
ADRES DO KORESPONDENCJI \\ lek. Katarzyna Warzecha \\ Uniwersyteckie Centrum Kliniczne im. prof. K. Gibińskiego, \\ Śląski Uniwersytet Medyczny \\ 40-514 Katowice, ul. Ceglana 35 \\ e-mail: katarzynaarabasz@interia.pl
}

\author{
ORCID \\ Katarzyna Warzecha - ID - http://orcid.org/0000-0001-6926-6761 \\ Agnieszka Tronina - ID - http://orcid.org/0000-0002-3651-4017 \\ Erita Filipek - ID - http://orcid.org/0000-0002-4227-1349
}

\section{Piśmiennictwo}

1. Partyka I. Zalecane algorytmy postępowania w retinopatii cukrzycowej wg AAO. Okul Dypl. 2016; 6(6): 31-9.

2. Engd N. Diabetes Control and Complications Trial/Epidemiology of Diabetes Interventions and Complications Research Group. Retinopathy and nephropathy. In: Patients with type 1 diabetes four years after a trial of intensive therapy. J Med. 2000; 342: 381-9.

3. Writing Team for the Diabetes Control and Complications Trial/Epidemiology of Diabetes Interventions and Complications Research Group. Effect of intensive therapy on the microvascular complications of type 1 diabetes mellitus. JAMA. 2002; 287: 2563-9.

4. Diabetes Control and Complications Trial Research Group. Progression of retinopathy with intensive versus conventional treatment In the Diabetes Control and Complications Trial. Ophthalmology. 1995; 102: 647-61.

5. Diabetes Control and Complications Trial Research Group. The relationship of glycemic exposure (HbA1c) to the risk of development and progression of retinopathy In the Diabetes Control and Complications Trial. Diabetes. 1995; 44: 968-83.

6. Bowling B, Kański JJ. Okulistyka kliniczna. Wydanie 8. Elsevier Urban \& Partner, Wrocław 2017: 506-8, 520-56, 561-9, 603-4, 615-7, 623-30, 681-700, 797-8.

7. Gawęcki M. Micropulse Laser Treatmentof Retinal Diseases. J Clin Med. 2019; 8(2): 242.

8. Fotokoagulacja. Leczenie proliferacyjnej retinopatii cukrzycowej. Zastosowanie kliniczne wyników badań retinopatii cukrzycowej (DRS), numer raportu DRS 8. Grupa badawcza ds. retinopatii cukrzycowej. Okulistyka. 1981; 88: 583-600.

9. Early Treatment Diabetic Retinopathy Study Research Group. Early photocoagulation for diabetic retinopathy. ETDRS Report Number 9. Ophthalmology. 1991; 98: 766-85.

10. Gross JG, Glassman AR, Jampol LM et al. Writing Committee for the Diabetic Retinopathy Clinical Research Network. Panretinal Photocoagulation vs Intravitreous Ranibizumab for Proliferative Diabetic Retinopathy: A Randomized Clinical Trial. JAMA. 2015; 314: $2137-46$.

11. Sivaprasad S, Prevost AT, Vasconcelos JC et al. Clinical efficacy of intravitreal aflibercept versus panretinal photocoagulation for best corrected visual acuity in patients with proliferative diabetic retinopathy at 52 weeks (CLARITY): A multicentre, single-blinded, randomised, controlled, phase 2b, non-inferiority trial. Lancet. 2017; 389: 2193-203.

12. Ho AC, Scott IU, Kim SJ et al. Anti-vascular endothelial growth factor pharmacotherapy for diabetic macular edema: a report by the AAO. Ophthalmology. 2012; 119: 2179-88.

13. Mitchell P, Bandello F, Schmidt-Erfurth U et al. Restore Study Group: Ranibizumab monotherapy of combined with laser versus laser monotherapy for diabetic macular edema. Ophthalmology. 2011; 118: 615-25.

14. Nguyen QD, Brown DM, Marcus DM et al. Ranibizumab for diabetic macular edema: results from 2 phase III randomized trials: RISE and RIDE. Ophthalmology. 2012; 119: 789-801.

15. Rek M, Jurowski P. Wytyczne EURETINA dotyczące diagnostyki i leczenia cukrzycowego obrzęku plamki żółtej. Okul Dypl. 2018; 8(4): 11-20.

16. Schmidt-Erfurth U, Garcia-Arumi J, Bandello F et al. Guidelines for the Management of Diabetic Macular Edema by the European Society of Retina Specialists (EURETINA). Ophthalmologica. 2017; 237(4): 185-222.

17. Latalska M, Mackiewicz J. Cukrzycowy obrzęk plamki - diagnostyka i leczenie. Okul Dypl. 2018; 8(2): 5-10.

18. Gaca-Wysocka M, Grzybowski M. Zastosowanie lasera nanosekundowego 2RT w leczeniu cukrzycowego obrzęku plamki. OphthaTherapy. 2017; 4(2): 81-4.

19. Pelosini L, Hamilton R, Mohamed M et al. Retina rejuvenation therapy for diabetic macular edema. Retina. 2013; 33: 548-58.

20. Wytyczne postępowania w terapii cukrzycowego obrzęku plamki Polskiego Towarzystwa Okulistycznego. 2017.

21. Wytyczne leczenia obrzęku plamki wtórnego do niedrożności naczyń żylnych siatkówki Polskiego Towarzystwa Okulistycznego. 2014.

22. Kuklo P, Kuklo M, Pieczyński J et al. Laserowe leczenie chorób obturacyjnych naczyń siatkówki. Okul Dypl. 2019; 9(6): 5-9.

23. Li C, Wang R, Liu G et al. Efficacy of panretinal laser in ischemic central retinal vein occlusion: A systemic review. Exp Ther Med. 2019; 17(1): 901-10.

24. Central vein occlusion study of photocoagulation therapy. Baseline findings. Central vein occlusion study group. Online J Curr Clin Trials. 1933; 95.

25. Rehak M, Wiedemann P. Retinal vein thrombosis: pathogenesis and management. J Thromb Haemost. 2010; 8(9): 1886-94.

26. Li J, Paulus Y, Shuai Y et al. New Developments In the Classification, Pathogenesis, Risk Factors, Natural History and Treatment of Branch Retinal Vein Occlusion. J Ophthalmol. 2017; 3: 1-18.

27. Zhou JQ, Xu L, Wang S et al. The 10-year incidence and risk factors of retinal vein occlusion: the Beijing eye study. Ophthalmology. 2013; 120(4): 803-8.

28. Campochiaro PA, Hafiz G, Mir TA et al. Scatter photocoagulation does not reduce macular edema or treatment burden in patients with retinal vein occlusion: the RELATE trial. Ophthalmology. 2015; 122(7): 1426-37. 
29. Gunther JB, Altaweel MM. Bevacizumab (Avastin) for the treatment of ocular disease. Survey of Ophthalmology. 2009; 54(3): 372-400.

30. Smiddy WE. Economic considerations of macular edema therapies. Ophthalmology. 2011; 118(9): 1827-33.

31. Tomomatsu Y, Tomomatsu T, Takamura Y et al. Comparative study of combined bevacizumab/targeted photocoagulation vs bevacizumab alone for macular oedema in ischaemic branch retinal vein occlusions. Acta Ophthalmologica. 2016; 94(3): 225-30.

32. Yang CS, Liu JH, Chung YC et.al. Combination therapy with intravitreal bevacizumab and macular grid and scatter laser photocoagulation in patients with macular edema secondary to branch retinal vein occlusion. J Ocul Pharmacol Th. 2015; 31(3): 179-85.

33. Donati S, Barosi P, Bianchi M et al. Combined intravitreal bevacizumab and grid laser photocoagulation for macular edema secondary to branch retinal vein occlusion. Eur J Ophthalmol. 2012; 22(4): 607-14.

34. Shimura M, Yasuda K. Topical bromfenac reduces the frequency of intravitreal bevacizumab in patients with branch retinal vein occlusion. Br J Ophthalmol. 2015; 99(2): 215-19.

35. Ma J, Yao K, Zhang Z et al. 25-gauge vitrectomy and triamcinolone acetonide-assisted internal limiting membrane peeling for chronic cystoid macular edema associated with branch retinal vein occlusion. Retina. 2008; 28(7): 947-56.

36. Pichi F, Specchia C, Vitale L et al. Combination therapy with dexamethasone intravitreal implant and macular grid laser in patients with branch retinal vein occlusion. Am J Ophthalmol. 2014; 157(3): 607-15.

37. Hwang JC, Gelman SK, Fine HF et al. Combined arteriovenous sheathotomy and intraoperative intravitreal triamcinolone acetonide for branch retinal vein occlusion. Brit J Ophthalmol. 2010; 94(11): 1483-9.

38. Riese J, Loukopoulos V, Meier C et al. Combined intravitreal triamcinolone injection and laser photocoagulation in eyes with persistent macular edema after branch retinal vein occlusion. Graefes Arch Clin Exp Ophthalmol. 2008; 246(12): 1671-6.

39. Azad SV, Salman A, Mahajan D et al. Comparative evaluation between ranibizumab combined with laser and bevacizumab combined with laser versus laser alone for macular oedema secondary to branch retinal vein occlusion. Middle East Afr J Ophthalmol. 2014; 21(4): 296-301.

40. Ozkaya A, Celik U, Alkin Z et al. Comparison between intravitreal triamcinolone with grid laser photocoagulation versus bevacizumab with grid laser photocoagulation combinations for branch retinal vein occlusion. ISRN Ophthalmology. 2013: 8.

41. Ali R.I, Kapoor KG, Khan AN et al. Efficacy of combined intravitreal bevacizumab and triamcinolone for branch retinal vein occlusion. Indian J Ophthalmol. 2014; 62(4): 396-9.

42. Parodi MB, lacono P, Ravalico G. Intravitreal triamcinolone acetonide combined with subthreshold grid laser treatment for macular oedema in branch retinal vein occlusion: a pilot study. Brit J Ophthalmol. 2008; 92(8): 1046-50.

43. Tsujikawa A, Fujihara M, Iwawaki T et al. Triamcinolone acetonide with vitrectomy for treatment of macular edema associated with branch retinal vein occlusion. Retina. 2005; 25(7): 861-7.

44. Schmidt-Erfurth U, Garcia-Arumi J, Gerendas BS. Guidelines for the management of Retinal Vein Occlusion by the European Society of Retina Specialists (EURETINA). Ophthalmologica. 2019; 242(3): 123-62.

45. Varma DD, Cugati S, Lee AW et al. A review of central retinal artery occlusion: clinical presentation and management. Eye (Lond). 2013; 27(6): 688-97.

46. Opremcak E, Rehmar AJ, Ridenour CD et al. Restoration of retinal blond flow via transluminal Nd:YAG embolysis/embolectomy (TYL/E) for central and branch retinal artery occlusion. Retina. 2008; 28(2): 226-35.

47. Chai F, Du S, Zhao X et al. Reperfusion of occluded branch retinal arterie by trans luminal Nd:YAG laser embolysis combined with intravenous thrombolysis of urokinase. Biosci Rep. 2018; 38(1).

48. Brązert A, Kocięcki J. Oczny zespół niedokrwienny. Okul Dyp. 2018; 8(1): 21-25.

49. Barnett HM, Taylor DW, Eliasziw M et al. Benefit of carotid endarterectomy in patients with symptomatic moderate or severe stenosis. North American Symptomatic Carotid Endarterectomy Trial Collaborators. N Engl J Med. 1998; 339(20): 1415-25.

50. Hazin R, Daoud YJ, Khan F. Ocular ischemic syndrome: recent trends In medical management. Curr Opin Ophthalmol. 2009; 20(6): 430-3.

51. Mrejen S, Spaide RF. Optical coherence tomography: Imaging of the choroid and beyond. Surv Ophthalmol. 2013; 58: 387-429.

52. Rochepeau C, Kodjikian L, Garcia MA et al. OCT-Angiography Quantitative Assessment of Choriocapillaris Blood Flow in Central Serous Chorioretinopathy. Am J Ophthalmol. 2018; 194: 26-34.

53. Cakir B, Reich M, Lang SJ et al. Possibilities and Limitations of OCT-Angiography in Patients with Central Serous Chorioretinopathy. Klin Monbl Augenheilkd. 2017; 234: 1161-8.

54. Arora S, Sridharan P, Arora T et al. Subthreshold diode micropulse laser versus observation in acute central serous chorioretinopathy. Clin Exp Optom. 2019; 102: 79-85.

Wkład autorów:

Katarzyna Warzecha: 60\%; Agnieszka Tronina: 10\%; Erita Filipek: 30\%.

Konflikt interesów:

Nie występuje.

Finansowanie:

Nie występuje.

Etyka:

Treści przedstawione w artykule sa zgodne z zasadami Deklaracji Helsińskiej, dyrektywami EU oraz ujednoliconymi wymaganiami dla czasopism biomedycznych.
Authors' contributions:

Katarzyna Warzecha: 60\%; Agnieszka Tronina: 10\%; Erita Filipek: 30\%.

Conflict of interest:

None.

Financial support:

None.

Ethics:

The content presented in the article complies with the principles of the Helsinki Declaration, EU directives and harmonized requirements for biomedical journals. 